\title{
MENGURANGI KEJENUHAN BELAJAR DENGAN KONSELING KELOMPOK TEKNIK KONTRAK PERILAKU KELAS X MULTIMEDIA 3 SMKN 1 JETIS
}

\author{
Etik Sulistyowati, S.Pd. \\ SMK Negeri 1 Jetis \\ etik.sulis@gmail.com \\ Fitrah Romadhoni Laily
SMK Negeri 1 Lumajang
fitra.rl@gmail.com
}

\begin{abstract}
Abstrak
Dimasa pandemik ini, SMKN 1 Jetis melakukan pembelajaran dilakukan secara daring. Pembelajaran daring ini tidak lepas dari suatu permasalahan juga, hal ini di tunjukkan dari aplikasi edmodoo terdapat siswa yang dalam pengumpulan tugas progress yang dimiliki hanya 40\%. Setelah di observasi ternyata mereka mengalami kejenuhan belajar, Adapun cirinya adalah cemas, bosan, tidak semangat dalam belajar sehingga mereka cenderung meninggalkan tugas-tugas sekolahnya. Factor yang menyebabkan adalah penggunaan metode belajar yang tidak bervariasi, belajar hanya di lakukan ditempat tertentu saja, kurangnya aktivitas rekreasi dan adanya ketegangan mental dalam belajar. Tujuan dari penelitian ini untuk mengetahui konseling kelompok teknik kontrak perilaku dapat mengurangi kejenunuhan belajar siswa kelas X MM 3 SMKN 1 Jetis. Metode yang di gunakan dalam penelitian ini adalah observasi dan pengukuran skala kejenuhan belajar. Penelitian ini menggunakan 2 siklus dengan menggunakan pretest dan postest, Adapun hasil yang di peroleh pada siklus 1 rata-rata kejenuhan belajar 131.8 dan pada siklus ke 2 rata-rata kejenuhan belajar 88,8. Sehingga dapat di simpulkan bahwa konseling kelompok kontrak perilaku dapat menurunkan kejenuhan belajar siswa.
\end{abstract}

Kata Kunci: kejenuhan belajar, konseling kelompok, kontrak perilaku

\begin{abstract}
During this pandemic, SMKN 1 Jetis learning by online. This online learning cannot be separated from a problem either, this is shown from the edmodoo application that there are students who in the collection of progress assignments only have 40\%. After observing it, it turns out that they experience learning boredom. The characteristics are anxious, bored, not enthusiastic in learning so they tend to leave their school assignments. Factors that cause are the use of learning methods that do not vary, learning is only done in certain places, lack of recreational activities and the presence of mental tension in learning. The purpose of this study was to determine the behavioral contract technique group counseling can reduce student learning outcomes of class X MM 3 SMKN 1 Jetis. The method used in this research is observation and measurement of the learning saturation scale. This study used 2 cycles using the pretest and posttest. The results obtained in the first cycle of learning saturation an average of 131.8 and in the average cycle of learning saturation 88.8. So it can be concluded that behavioral contract counseling can reduce student learning boredom.
\end{abstract}

Keywords: Exploration, Esed Materials, Project Based Learning 
Bimbingan dan Konseling Universitas PGRI Adi Buana Surabaya

ISSN: 02162938

\section{LATAR BELAKANG}

Dimasa pandemic ini SMKN 1 Jetis melakukan pembelajaran dilakukan secara daring. Pembelajaran daring ini tidak lepas dari suatu permasalahan juga, hal ini di tunjukkan dari aplikasi edmodoo terdapat siswa yang dalam pengumpulan tugas progress yang dimiliki hanya $40 \%$. Setelah di observasi ternyata mereka mengalami kejenuhan belajar, Adapun cirinya adalah cemas, bosan, tidak semangat dalam belajar sehingga mereka cenderung meninggalkan tugas-tugas sekolahnya. Factor yang menyebabkan adalah penggunaan metode belajar yang tidak bervariasi, belajar hanya di lakukan ditempat tertentu saja, kurangnya aktivitas rekreasi dan adanya ketegangan mental dalam belajar.

menurut Suwarjo \& Diana Septi Purnama (2016: 12) mengartikan Burnout sebagai suatu keadaan keletihan (exhaustion) fisik, emosional dan mental dimana cirinya sering disebut physical depletion, yaitu dicirikan dengan perasaan tidak berdaya dan putus harapan, keringnya perasaan, konsep diri yang negatif dan sikap yang negatif dan perasaan gagal untuk mencapai tujuan diri yang ideal. Dari pendapat tersebut maka dapat diperoleh kesimpulan bahwa kejenuhan belajar terjadi akibat dari adanya tuntutan bagi peserta didik untuk selalu mematuhi aturan tugastugas yang diembankan untuk peserta didik. Kejenuhan belajar juga terjadi karena kegiatan yang selalu sama yang dikerjakan oleh peserta didik disetiap harinya. Kejenuhan belajar ini akan sangat berdampak bagi peserta didik untuk keberlangsungan pendidikannya. Hal ini membuktikan bahwa siswa cenderung mengalami kejenuhan dalam proses belajarnya karena siswa cenderung untuk meninggalkan tugas-tugas mereka.

Untuk mengatasi permasalahan di atas bimbingan dan konseling memiliki peranan yang penting dalam menangani permasalahan siswa. Berdasarkan hasil observasi dimana di kelas X MM 3 ada beberapa siswa yang malas mengumpulkan tugas daring yang di berikan oleh Bapak/Ibu guru. Hal ini di sebakan karena mereka mempunyai kejenuhan dalam belajar daring, karena mereka di tuntut untuk mengerjakan tugas dari Bapak/Ibu guru setiap hari dan kondisi tersebut berlangsung setiap hari di depan HP atau laptop. Dari masalah tersebut upaya untuk mengatasi kejenuhan belajar adalah menggunakan konseling kelompok teknik behavioral kontrak perilaku, dengan konseling kelompok pendekatan behavioral kontrak perilaku diharapkan peserta didik bisa mengatasi kejenuhan belajar yang mereka alami. Dalam konseling individual kontrak perilaku ini konseli diajak untuk membuat komitmen dengan membuat kontrak, karena teknik ini merupakan teknik yang dapat mengatasi perubahan perilaku yang dari proses belajar yang salah dari lingkungan. Maka dari itu untuk mengatasi hal tersebut maka peneliti mengambil judul "Mengurangi kejenuhan belajar dengan konseling kelompok teknik kontrak perilaku kelas X Mulitimedia 3 SMK Negeri 1 Jetis Tahun Pelajaran 2020/2021 “

\section{METODOLOGI}

Penelitian ini menggunakan penelitian tindakan kelas atau di sebut dengan PTBK dengan 2 siklus, yang terdiri dari 4 tahap kegiatan, yaitu perencanaan, tindakan, pengamatan, dan refleksi.

Pada tahap perencanaan peneliti Menyusun; (1) Jadwal kegiatan layanan konseling kelompok, (2) RPLBK layanan konseling kelompok yang terdiri dari 2 kali pertemuan setiap pertemuan 45 menit, materi layanan konseling kelompok yang berisi gejala kejenuhan belajar, sebabsebab kejenuhan belajar dan strategi kontrak perilaku, (3) instrument yang sudah tervalidasi yang berupa skala pengukuran kejenuhan

Pada tahap tindakan, peneliti memberikan tindakan berupa layanan konseling kelompok stategi kontrak perilaku kepada siswa yang mengalami kejenuhan belajar tinggi. Adapun alokasi waktunya 30 menit 2 kali pertiemuan dengan menggunakan RPLBK, materi, LKPD dan media yang telah di siapkan. Selang 2 hari setelah diadakan konseling kelompok di berikan skala kejenuhan belajar yang harus di isi oleh siswa dan 
dilakukan analisis data.

Populasi penelitian ini adalah para siswa kelas $\mathrm{X}$ MM 3 SMKN 1 Jetis Mojokerto yang berjumlah 36 orang, sampel penelitian sebanyak 5 orang siswa yang diperoleh dengan menggunakan teknik random melalui undian kelas. Data penelitian dikumpulkan dengan menggunakan skala kejenuhan belajar yang teruji validitasnya $0,357-0,767$ dan reabilitasnya 0,952 .

\section{HASIL}

\begin{tabular}{cccc|ccc} 
dan & \multicolumn{3}{c|}{ Siklus 1 } & \multicolumn{3}{c}{ Siklus 2 } \\
\hline No & Nama & Skor & Ket & Skor & Ket & Penurunan \\
\hline 1 & ES & 148 & Tinggi & 94 & Rendah & 51 \\
\hline 2 & FR & 140 & sedang & 118 & Sedang & 14 \\
\hline 3 & FA & 125 & sedang & 86 & Rendah & 39 \\
\hline mpel 4 & SA & 130 & sedang & 107 & Sedang & 20 \\
\hline kala 5 & HN & 148 & Tinggi & 85 & rendah & 63 \\
\hline
\end{tabular}
kejenuhan belajar katagori tinggi. Adapun siswa tersebut di sajikan pada table 1.1

Tabel 1.1. Data Siswa yang Memiliki Kejenuhan Tinggi Sebelum Tindakan

\begin{tabular}{cccc}
\hline No & Nama & Skor & Ket \\
\hline 1 & ES & 164 & Tinggi \\
\hline 2 & FR & 148 & Tinggi \\
\hline 3 & FA & 148 & Tinggi \\
\hline 4 & SA & 150 & Tinggi \\
\hline 5 & HN & 151 & Tinggi \\
\hline
\end{tabular}

Berdasarkan data di atas 5 siswa tersebut mengalami kejenuhan belajar yang di sebabkan karena dalam belajar metode belajar yang di gunakan sama, kurang aktivitas rekresi, dan terjadi ketegangan mental. Sehingga mereka merasa cemas, bosan dan tidak bersemangat akibatnya mereka meninggalkan tugas-tugas yang diberikan oleh Bapak/Ibu guru. Untuk mengatasi hal tersebut di lakukan konseling kelompok teknik kontrak perilaku untuk mengurangi kejenuhan belajar mereka.

Setelah diberikan konseling kelompok teknik kontrak perilaku di peroleh skor kejenuhan belajar sebagai berikut:

Tabel 1.2. Data Kejenuhan siswa siklus 1 setelah Konseling Kelompok

\begin{tabular}{cccc}
\hline No & Nama & Skor & Ket \\
\hline 1 & ES & 148 & Tinggi \\
\hline 2 & FR & 140 & Sedang \\
\hline 3 & FA & 125 & Sedang \\
\hline 4 & SA & 130 & Sedang \\
\hline 5 & HN & 148 & Tinggi \\
\hline
\end{tabular}

Setelah diberikan konseling kelompok sudah ada penurun dari katagori tinggi ke sedang tapi belum secar signifikan karena masih ada 2 siswa yang masih mengalami kejenuhan tinggi, maka dari itu di berikan konseling kelompok teknik kontrak perilaku lagi dengan penambahan opsi kontrak yang akan di lakukan oleh siswa.

Setelah dilakukan konseling kelompok kontrak perilaku siklus ke 2 menghasilkan data sebagai berikut:

\section{PEMBAHASAN}

Hasil penelitian ini menunjukan bahwa kejenuhan belajar dapat di turunkan dengan konseling kelompok teknik kontrak perilaku, dimana penuruna siklus 1 ke siklus 2 rata-ratanya 37,4. Dan dapat di lihat dari grafik di bawah ini:

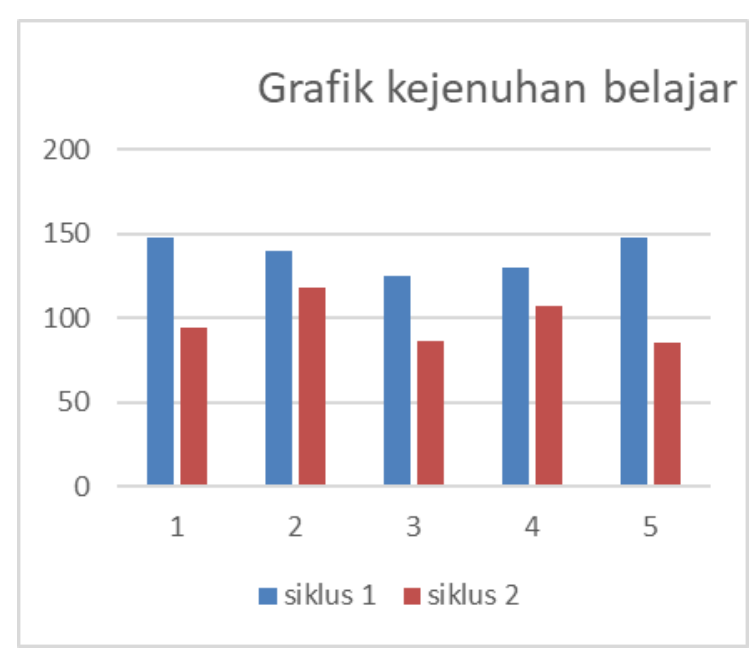

Berdasarkan grafik diatas bahwa kejenuhan belajar pada siklus pertama yang rata-rata kejenuhannya 138,2 yang termasuk katagori sedang setelah di berikan layanan konseling kelompok, kemudian pak siklus ke dua di berikan konseling kelompok lagi dengan strategi kontrak perilaku dengan menambahkan opsi kontrak yang harus di lakukan siswa terdapat penurun kejenuhan belajar ratarata menjadi 97 dengan katagori rendah. Berdasarkan dari grafik diatas dapat di simpulkan rata-rata kejenuhan belajar dari siklus 1 ke siklus 2 terdapat penurunan setelah di berikan konseling kelompok. 
Bimbingan dan Konseling Universitas PGRI Adi Buana Surabaya

ISSN: 02162938

\section{KESIMPULAN DAN SARAN}

Berdasarkan analis data di atas dapat di simpulkan bahwa kejenuhan belajar dapat di turunkan dengan konseling kelompok kontrak perilaku, dimana siswa harus mentaati kontrak perilaku yang telah di sepakati untuk usaha dalam mengurangi kejenuhan belajar yang di hadapi.

Tentunya hasil dari penelitian ini masih sangat jauh dari kata sempurna maka dari itu saran untuk semua pihak adalah terus mengembangkan dan mengupdate kemampuan dalam melakukan dan menggunakan teknik dan teori konseling dalam membantu menyelsaikan masalah konseli atau siswa. pemberian treatment masih bias dilakukan secara berkala kepada siswa yang bersangkutan. Karena hasil masih menunjukan taraf sedang sehingga masih memungkinkan untuk menurun kembali.

\section{DAFTAR RUJUKAN}

Hartini nurul, Atika Dia Ariana (2016) Psikologi konseling: Perkembangan dan penerapan konseling dalam psikologi. Surabaya: Airlangga University Press

Ilham Mubarok. 2018. Upaya Menurunkan

Kejenuhan Belajar Melalui Bimbingan Kelompok Teknik Games pada Siswa Kelas XI Akuntansi SMK YPKK 2 Sleman. Program Studi Bimbingan Dan Konseling Fakultas Ilmu Pendidikan.Universitas Negeri Yogyakarta

IPt. Edi Sutarjo, Dewi Arum WMP., Ni. Kt. Suarni. 2014. "Efektifitas teori Behavioral Teknik Relaksasi dan Brain Gym untuk Menurukan Burnout Belajar pada Siswa Kelas VIII SMP Laboratorium UNDIKSHA Singaraja Tahun Pelajaran 2013/2014”. Ejournal Undiksa. Volume: 2 No 1. Diakses dari: http://ejournal.undiksha.ac.id/index.p hp/JJBK/article/viewFile/3740/2995.

Mappiare, Andi. AT. 2011. Pengantar Konseling dan Psikoterapi. Edisi Kedua. Jakarta: Raja Grafindo Persadaa

Prayitno dan Erman Amati. (2015) DasarDasar Bimbingan dan Konseling, Jakarta: Rineka Cipta.

Suwarjo \& Diana Septi Purnama. 2016. Model Bimbingan Pengembangan Kompetensi Pribadi Sosial Bagi Siswa Sma yang Mengalami Kejenuhan Belajar (Burnout). Yogyakarta: Lumbung Pustaka 